\section{Biocatalytic Polytransesterification of Inulin with Divinyladipate}

Lino Ferreira and Maria H. Gil

Departamento de Engenharia Química, Universidade de Coimbra, Pinhal de Marrocos, 3030 Coimbra, Portugal

\author{
Rui Carvalho and Carlos F. G. C. Geraldes
}

Departamento de Bioquímica, Universidade de Coimbra, Apartado 3126, 3000 Coimbra, Portugal

Dae-Yun Kim and J onathan S. Dordick*

Department of Chemical Engineering, Rensselaer Polytechnic Institute, 102 Ricketts Building, Troy, New York 12180

Received April 16, 2002 Revised Manuscript Received August 26, 2002

Enzymatic synthesis of polymers has attracted significant attention in recent years ${ }^{1}$ because of high inherent selectivity under mild reaction conditions. A wide range of polymers has been synthesized using purely enzymatic means, including polyphenols, ${ }^{2}$ polyesters, ${ }^{3}$ and polycarbonates. ${ }^{4}$ Although the vast majority of polymers have been prepared from rather simple monomers, enzymes offer the opportunity to incorporate complex polyfunctional compounds, such as sugars and polysaccharides, into polymer backbones, ${ }^{5}$ thereby extending the synthetic repertoire of polymer chemistry.

In the current work, we report the enzyme-catalyzed polytransesterification of inulin with divinyladipate (DVA) in DMF to produce inulin polyesters. Inulin is composed by a mixture of oligomers and polymers containing 2 to 60 (or more) $\beta 2-1$ linked D-fructose molecules having a glucose unit as the initial residue. ${ }^{6}$ Six proteases and five lipases, all commercially available, were tested for their abilities to catalyze the polytransesterification of inulin with DVA in anhydrous DMF (Scheme 1), at $50{ }^{\circ} \mathrm{C}$, for $72 \mathrm{~h}$ (Table 1). ${ }^{7}$ There was significant variation in the inulin conversion (based on consumption of native inulin) and molecular weight ${ }^{8}$ obtained as a function of the enzyme, but in all cases the products were water soluble. Proleather, an alkaline protease from Bacillus subtilis, showed the highest conversion. ${ }^{9}$

* To whom correspondence should be addressed. Phone: 518-2762899. Fax: 518-276-2207. E-mail: dordick@rpi.edu.

(1) Akkara, J. A.; Ayyagari, M. S. R.; Bruno, F. F. TIBTECH 1999, 17, 67. Kaplan, D. L.; Dordick, J . S.; Gross, R. A.; Swift, G. Enzymes in Polymer Synthesis, ACS 684; Gross, R. A., Kaplan, D. L., Swift, G., Eds.; American Chemical Society: Washington, DC, 1996; pp 1-15.

(2) Dordick, J. S.; Marletta, M. A.; Klibanov, A. M. Biotechnol. Bioeng. 1987, 30, 31.

(3) Kline, B. J .; Lele, S. S.; Lenart, P. J .; Beckman, E. J .; Russell, A. J . Biotechnol. Bioeng. 2000, 67, 424. Bisht, K. S.; Henderson, L. A.; Gross, R. A.; Kaplan, D. L.; Swift, G. Macromolecules 1997, 30, 2705.

(4) Al-Azemi, T. F.; Bisht, K. S. Macromolecules 1999, 32, 6536. Bisht, K. S.; Svirkin, Y. Y.; Henderson, L. A.; Gross, R. A.; Kaplan, D. L.; Swift, G. Macromolecules 1997, 30, 7735.

(5) Patil, D. R.; Rethwisch, D. G.; Dordick, J . S. Biotechnol. Bioeng. 1991, 37, 639. Park, O.-J .; Kim, D.-Y.; Dordick, J . S. Biotechnol. Bioeng. 2000, 70, 208.

(6) Roberfroid, M. B.; Van Loo, J . A. E.; Gibson, G. R. J . Nutr. 1998, 128,11 .
Scheme 1. Schematic Representation of Enzyme-Polytransesterification of Inulin with DVA

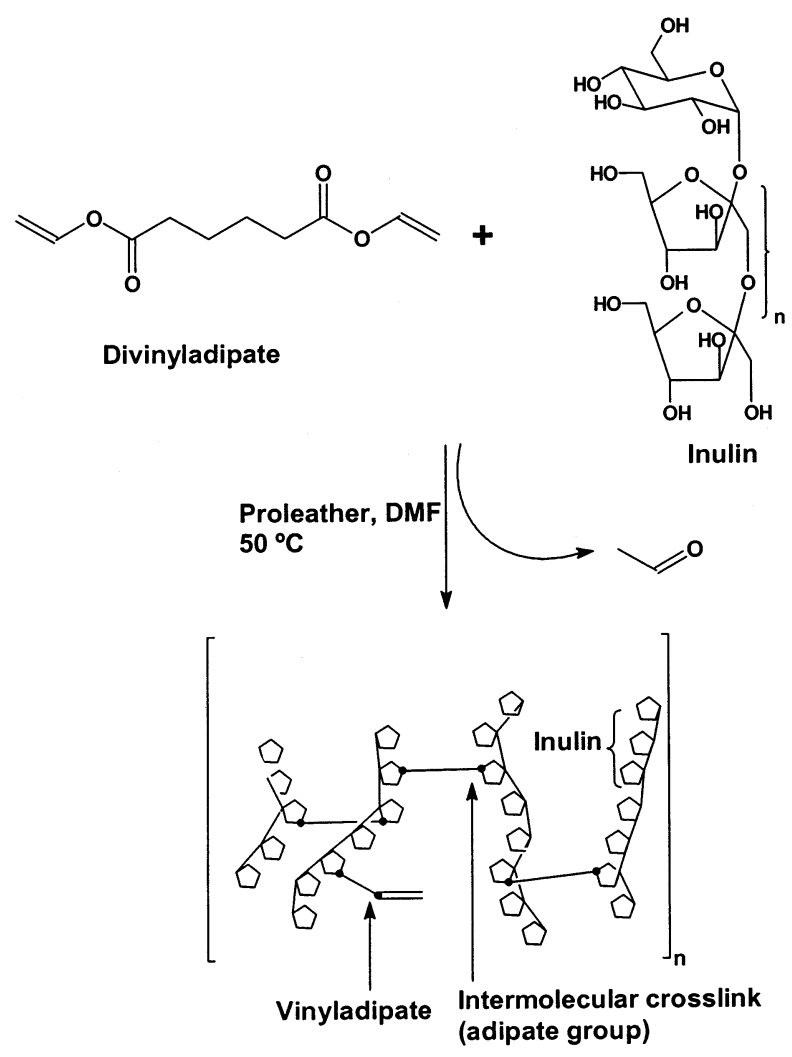

The number average molecular weight $\left(M_{n}\right)$ of the polymer formed was also influenced by the source of the enzyme, and this was mainly due to the extent of reaction conversion, an expected finding given the mechanism of $A A-B B$ polycondensation reactions. ${ }^{10}$ The relatively high polydispersities are expected with such a mechanism given the large size of the inulin "monomers" in the polymerization reaction. The polymer obtained using Proleather consisted of ca. 3-4 inulin molecules linked through adi pate moieties, yet remained water soluble, indicating that it was not heavily crosslinked.

(7) The enzymes were "pH-adjusted" prior to use in the presence of $20 \mathrm{mM}$ phosphate buffer at pH 8.0 (Proleather, Protease S, and subtilisin Carlsberg) or at pH 7.5 (Proteases A, N, and P, and Lipases $A, A Y, M, P S$, and Porcine Pancreas) following the procedure by Klibanov (Klibanov, A. M. CHEMTECH 1986, 16, 354). After being flash-frozen in liquid nitrogen, the samples were lyophilized on a Labconco freeze-drier (Labconco Corp., Kansas City, MO) for 48 h. Enzymes were screened for their reactivity on inulin by adding 300 mg of Iyophilized enzyme powder (130 mg for subtilisin) to $15 \mathrm{~mL}$ of anhydrous DMF containing $17 \mathrm{mM}$ inulin $\left(\mathrm{M}_{\mathrm{n}}=3620 \mathrm{Da}, \mathrm{M}_{\mathrm{w}} / \mathrm{M}_{\mathrm{n}}=\right.$ 1.2, obtained from Fluka Chemie AG, Buchs, Switzerland) and 200 mM DVA ( $\mathrm{TCl}$, Portland, OR). The reaction mixtures were shaken (250 rpm) at $50{ }^{\circ} \mathrm{C}$ in a temperature-controlled New Brunswick Scientific C24 orbital shaker (Edison, $\mathrm{NJ}$ ) for $72 \mathrm{~h}$. The reactions were terminated by removing the enzyme (all enzymes were insoluble in DMF) by centrifugation at $4000 \mathrm{rpm}$ for $10 \mathrm{~min}$. The supernatants were precipitated in a 4-fold excess of acetone and the precipitates were subsequently dissolved in Milli-Q water and dialyzed using a regenerated cellulose dialysis tube with a 1000 MWCO (Spectrum, CA) for 2 days, at $4{ }^{\circ} \mathrm{C}$, against water. Afterwards, the aqueous solutions of Inulin polyesters [poly(Inul-DVA)] were Iyophilized for $48 \mathrm{~h}$. The conversion was determined by back-titration with $0.1 \mathrm{~N} \mathrm{HCl}$ using phenolphthalein as indicator. 
Table 1. Enzyme Screening for the Polytransesterification Reaction of Inulina with DVA

\begin{tabular}{|c|c|c|c|c|c|}
\hline entry & enzyme & origin & conv. $(\%)^{d}$ & $M_{n}{ }^{e}$ & $M_{w} / M_{n}$ \\
\hline 1 & Proleather FG-Fb & Bacillus subtilis & 56.8 & 14310 & 2.5 \\
\hline 2 & Protease $A^{b}$ & Aspergillus oryzae & 11.2 & 6130 & 1.8 \\
\hline 3 & Protease $\mathrm{N}^{\mathrm{b}}$ & Bacillus subtilis & 8.4 & 5420 & 1.9 \\
\hline 4 & Protease $\mathrm{P}^{\mathrm{b}}$ & Aspergillus melleus & 17.2 & 7590 & 2.1 \\
\hline 5 & Protease $S^{b}$ & Bacillus stearothermophilus & 3.8 & 5560 & 1.1 \\
\hline 6 & Protease Subtilisin Carlsbergc & Bacillus licheniformis & 6.2 & 5780 & 2.3 \\
\hline 7 & Lipase $A^{b}$ & Aspergillus niger & 14.4 & 6640 & 2.2 \\
\hline 8 & Lipase AYb & Candida rugosa & 36.4 & 9820 & 3.9 \\
\hline 9 & Lipase Mb & Mucor javanicus & 20.0 & 8170 & 2.3 \\
\hline 10 & Lipase PSb & Pseudomonas cepacia & 21.6 & 8000 & 2.3 \\
\hline 11 & Lipase Porcine Pancreasc & Porcine pancreas & 2.4 & ND & ND \\
\hline
\end{tabular}

a The $M_{n}$ and $M_{w} / M_{n}$ of original Inulin were 3620 Da and 1.2, respectively. ${ }^{b}$ Obtained from Amano Enzyme Co (Troy, VA). ${ }^{c}$ Obtained from Sigma Chemical Co (St. Louis, MO). d Determined by titration. The conversion is defined as the percentage of DVA molecules incorporated into inulin taking into account the initial molar ratio of DVA to inulin fructose units in the reaction mixture. e The number average molecular weight was determined as described in ref 8. ND $=$ Not determined.

Table 2. DS Total, $_{\text {DS }} S_{\text {inyl, }} M_{n}$, and $M_{w} / M_{n}$ of Poly(Inul-DVA) as a Function of Initial Concentration of DVA Added to the Reaction ${ }^{a}$

\begin{tabular}{|c|c|c|c|c|c|c|}
\hline entry & $\begin{array}{c}\text { theoretical } \\
\text { DSb(\%) }\end{array}$ & $\begin{array}{l}\text { obtained } \\
\mathrm{DS}_{\text {total }} \mathrm{C}(\%)\end{array}$ & $\begin{array}{l}\text { obtained } \\
\text { DS }_{\text {vinyl }}{ }^{c}(\%)\end{array}$ & $\begin{array}{l}\text { efficiencyd } \\
\text { (\%) }\end{array}$ & $\mathrm{M}_{\mathrm{n}}^{\mathrm{e}}$ & $\mathrm{M}_{\mathrm{w}} / \mathrm{M}_{\mathrm{n}}$ \\
\hline 1 & 10 & 8.5 & 1.7 & 85.0 & 6690 & 2.6 \\
\hline 2 & 20 & 17.5 & 2.1 & 87.5 & 8760 & 3.1 \\
\hline 3 & 30 & 25.0 & 4.1 & 83.3 & 11360 & 3.3 \\
\hline 4 & 40 & 39.1 & 7.7 & 97.8 & 14610 & 3.5 \\
\hline 5 & 50 & 45.8 & 8.6 & 91.6 & $>14610^{f}$ & \\
\hline
\end{tabular}

a Reactions were performed in $30 \mathrm{~mL}$ of anhydrous DMF containing $17 \mathrm{mM}$ inulin and a calculated amount of DVA. The reaction mixtures were shaken at $250 \mathrm{rpm}$ and $50{ }^{\circ} \mathrm{C}$ for $140 \mathrm{~h}$, after which they were purified as before ${ }^{7}$ (isolated yields: $44-69 \%$ ). ${ }^{\mathrm{b}} \mathrm{Calculated}$ from the initial molar ratio of DVA to inulin fructofuranoside residues. ${ }^{\circ}$ Degree of substitution of the products (determined by ${ }^{1} \mathrm{H}$ NMR). ${ }^{d}$ Calculated as the ratio of the obtained DS total $_{\text {to }}$ the theoretical DS. e The number average molecular weight was determined as described in ref $8{ }^{f}$ Higher than the exclusion limit of the GPC column, circumventing any precise determination of $M_{n}$.

Poly(I nul-DVA) synthesized by Proleather was further analyzed by NMR $\left({ }^{1} \mathrm{H},{ }^{13} \mathrm{C} N M R\right.$, and 2-dimensional ${ }^{1} \mathrm{H}-{ }^{1} \mathrm{H}$ COSY and ${ }^{1} \mathrm{H}-{ }^{13} \mathrm{C}$ HMQC NMR; see Supporting Information). The calculation ${ }^{11}$ of $\mathrm{DS}_{\text {total }}$ (defined as the number of DVA molecules incorporated into inulin through single or double ester bonds per 100 inulin fructofuranoside residues) and $D_{\text {vinyl }}$ (defined as the number of DVA incorporated to inulin by single ester bonds, and hence retaining a vinyl ester moiety, per 100 inul in fructofuranoside residues) yielded 45.8 and $8.6 \%$ (the initial molar ratio of DVA to inulin fructofuranoside residues was 0.5$)$, respectively, which means that most of the DVA is incorporated into the inulin through

(8) Gel permeation chromatography (GPC) was performed with a Shimadzu LC-10AT (Columbia, MD) equipped with a Waters 410 refractive index detector (Milford, MA). The eluent was DMF at a flow rate of $0.5 \mathrm{~mL} / \mathrm{min}$. Waters 500 and $100 \AA$ Ultrastyragel $(7.5 \times 300$ $\mathrm{mm})$, and Styragel HR 5E $(4.6 \times 300 \mathrm{~mm})$ were installed in series to achieve effective separation of polymers. Calibration was made with polystyrene standards of narrow polydispersity in the molecular weight range from 762 to $44000 \mathrm{Da}$. Thus, the reported molecular weights are more accurately described as apparent molecular weights. The GPC chromatograms were obtained from samples dissolved in DMF over a concentration range of $2.1-2.4 \%(\mathrm{w} / \mathrm{v})$.

(9) Two controls were performed: in the absence of enzyme $<7 \%$ conversion was obtained, whereas with the use of thermally deactivated Proleather (i.e., boiled for $5 \mathrm{~h}$ followed by lyophilization) in place of the active enzyme $\left(50^{\circ} \mathrm{C}, 24 \mathrm{~h}\right)$, conversions of ca. $5 \%$ were obtained. These results indicate that the polytransesterification reaction proceeded through enzymatic catalysis.

(10) A plot of $M_{n}$ as a function of reaction conversion for the different enzymes studied is given in the Supporting Information. The high linearity is strongly indicative of an $\mathrm{AA}-\mathrm{BB}$ polycondensation reaction catalyzed by the different enzymes.

(11) On the basis of the ${ }^{1} \mathrm{H}$ NMR assignments, the $\mathrm{DS}_{\text {total }}$ was calculated as $\mathrm{DS}_{\text {total }}=(7 z / 4 \mathrm{y}) \times 100$, and $\mathrm{DS}_{\text {vinyl }}$ was calculated from $\mathrm{DS}_{\mathrm{viny}}=(7 \mathrm{w} / \mathrm{y}) \times 100$, where $\mathrm{w}$ is the integral of the vinyl proton at $\delta 7.15 \mathrm{ppm}, \mathrm{z}$ is the average integral of the protons from adi pate group in the range of $\delta 2.45-1.63 \mathrm{ppm}$, and $\mathrm{y}$ is the integral of all inulin protons between $\delta 5.38-5.05 \mathrm{ppm}$ and $\delta 4.50-3.38 \mathrm{ppm}$ (see Supporting Information). double ester bonds. Hence, adipate esters were incorporated as inter- or intramolecular cross-links on the inulin structure.

The structure of poly(Inul-DVA $)^{12}$ revealed one predominant positional isomer in the fructofuranoside residue at the 6-position and two minor isomers at the 3 and 4 positions (24.3:11.0:10.5, at the 6,4 , and 3 positions, respectively), showing the enzyme's preference for primary hydroxyl groups. ${ }^{13}$ Furthermore, the ${ }^{1} \mathrm{H}-{ }^{1} \mathrm{H}$ COSY NMR experiment indicated that the reacted fructose residues are monosubstituted as no cross-peaks were shared by the three positional isomers. Hence, the intramolecular cross-links were between different fructose residues on the same inulin chain. ${ }^{14}$

Encouraged by these results, we proceeded to study the effect of DVA concentration on DS total, $\mathrm{DS}_{\text {vinyl, }}$ and $M_{n}$ of Poly(Inul-DVA) (Table 2). In all cases, water-

(12) Poly(Inul-DVA) ${ }^{1} \mathrm{H}$ NMR results $\left(\delta, \mathrm{D}_{2} \mathrm{O}, \mathrm{ppm}\right): \delta 7.15(\mathrm{dd}, 1 \mathrm{H}$ $\left.\mathrm{H}_{\mathrm{x}}\right), 5.38\left(\mathrm{~m}, 2 \mathrm{H}, \mathrm{H}_{1 \mathrm{~g}}\right.$ and $\left.\mathrm{H}_{3 f^{f}}\right), 5.16\left(\mathrm{~m}, 2 \mathrm{H}, \mathrm{H}_{4 f^{\prime}}\right.$ and $\left.\mathrm{H}_{1 \mathrm{~g}}\right), 4.94(\mathrm{dd}$ $\left.1 \mathrm{H}, \mathrm{H}_{\mathrm{b}}\right), 4.69\left(\mathrm{dd}, 1 \mathrm{H}, \mathrm{H}_{\mathrm{a}}\right), 4.43\left(\mathrm{~d}, 1 \mathrm{H}, \mathrm{H}_{3 \mathrm{f}-4 \mathrm{f}}\right), 4.23\left(\mathrm{~m}, 3 \mathrm{H}, \mathrm{H}_{6 \mathrm{f}}\right.$ and $\left.\mathrm{H}_{4 f-3 f}\right), 4.20\left(\mathrm{~d}, 1 \mathrm{H}, \mathrm{H}_{3 f}\right), 4.04\left(\mathrm{t}, 1 \mathrm{H}, \mathrm{H}_{4 \mathrm{f}}\right), 3.90-3.50\left(\mathrm{~m}, 5 \mathrm{H}, \mathrm{H}_{5 f}, \mathrm{H}_{6}\right.$ and $\left.\mathrm{H}_{1 \mathrm{f}}\right), 2.45(\mathrm{~s}, 4 \mathrm{H}$, adipate), $1.63(\mathrm{~s}, 4 \mathrm{H}$, adipate). Poly(I nul-DVA) ${ }_{13} \mathrm{C}$ NMR results $\left(\delta, \mathrm{D}_{2} \mathrm{O}, \mathrm{ppm}\right): \delta 177.4-174.1(\mathrm{C}=\mathrm{O}), 142.7(\mathrm{HC}=$ $\left.\mathrm{CH}_{2}\right), 104.7\left(\mathrm{C}_{2 f}\right.$ and $\left.\mathrm{C}_{2 f-3 f}\right), 100.7\left(\mathrm{HC}=\mathrm{CH}_{2}\right), 94.3\left(\mathrm{C}_{1 \mathrm{~g}}\right), 82.6\left(\mathrm{C}_{5 f}\right)$, $81.3\left(\mathrm{C}_{5 f-4 f}\right), 80.2\left(\mathrm{C}_{3 f}\right), 79.9\left(\mathrm{C}_{5 f-6 f}\right), 78.8\left(\mathrm{C}_{4 f^{f}}\right), 78.5\left(\mathrm{C}_{3 f}\right), 76.8\left(\mathrm{C}_{3 f-4 f^{\prime}}\right)$ $76.6\left(\mathrm{C}_{4 f}\right), 75.8\left(\mathrm{C}_{4 f}\right), 74.3\left(\mathrm{C}_{4 f-3 f}\right), 66.5\left(\mathrm{C}_{6 f}\right), 63.6\left(\mathrm{C}_{6 f}\right), 62.4\left(\mathrm{C}_{1 f}\right), 34.8$ and $34.6\left(-\mathrm{CH}_{2}-\mathrm{CH}_{2}-\mathrm{CH}_{2}-\mathrm{CH}_{2}-\right.$, adipate), 25.2 and $24.9\left(-\mathrm{CH}_{2}-\right.$ $\mathrm{CH}_{2}-\mathrm{CH}_{2}-\mathrm{CH}_{2}-$, adipate). Inulin ${ }^{13} \mathrm{C}$ NMR results $\left(\delta, \mathrm{D}_{2} \mathrm{O}, \mathrm{ppm}\right): \delta$ $104.8\left(\mathrm{C}_{2 f}\right), 82.6\left(\mathrm{C}_{5 f}\right), 78.6\left(\mathrm{C}_{3 f}\right), 75.8\left(\mathrm{C}_{4 f}\right), 63.7\left(\mathrm{C}_{6 f}\right), 62.4\left(\mathrm{C}_{1 f}\right)$. The shifts observed from that of inulin are a downfield shift in $C_{6 f}, C_{4 f}$, and $\mathrm{C}_{3 f}$. This indicates the acylation of $\mathrm{C}_{6 f}, \mathrm{C}_{4 f}$, and $\mathrm{C}_{3 f}$ (denoted as $\mathrm{C}_{6 f}, \mathrm{C}_{4 f}$ and $\mathrm{C}_{3 f}$ ) according to $\mathrm{Y}$ oshimoto et al. (Y oshimoto, K.; I tatani, Y.; Tsuda, Y. Chem. Pharm. Bull. 1980, 28, 2065).

(13) Patil, D. R.; Dordick, J . S.; Rethwisch, D. G. Macromolecules 1991, 24, 3462. Riva, S.; Nonini, M.: Ottolina, G.; Danieli, B. Carbohydr. Res. 1998, 314, 259. Rich, J . O.; Bedell, B. A.; Dordick, J. S. Biotechnol. Bioeng. 1995, 45, 426.

(14) It was not possible to determine the intramolecular cross-links content by NMR spectroscopy. 

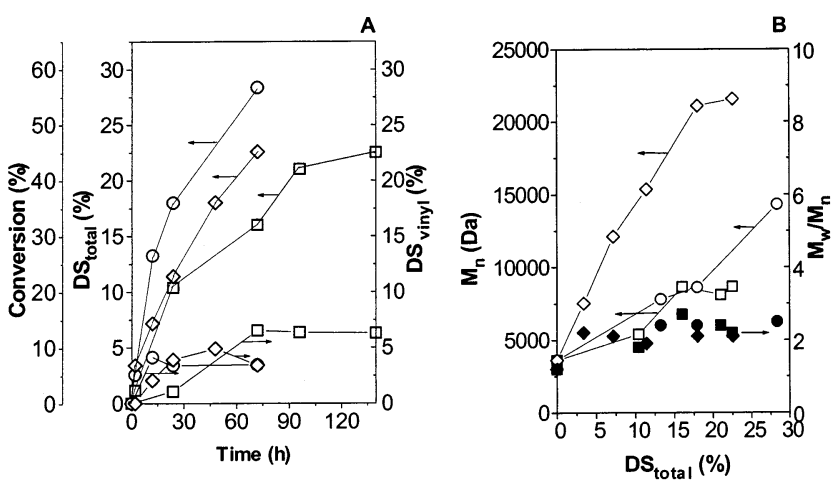

Figure 1. (A) DS $S_{\text {total }}$ and $D S_{\text {vinyl }}$ obtained as a function of time for the reaction of DVA with Inulin (molar ratio of DVA to I nulin fructofuranoside residues was 0.5 ) at a concentration of $6.7 \%(\mathrm{w} / \mathrm{v})$ in the presence of $10 \mathrm{mg} / \mathrm{mL}(\square), 20 \mathrm{mg} / \mathrm{mL}(\bigcirc)$, and $40 \mathrm{mg} / \mathrm{mL}(\diamond)$ Prol eather shaken at $250 \mathrm{rpm}$ at $50{ }^{\circ} \mathrm{C}$. DS values were determined by ${ }^{1} \mathrm{H}$ NMR (see text for details). (B) $M_{n}$ and $M_{w} / M_{n}$ as a function of $D S_{\text {total }}$.

soluble derivatized inulin polymers were obtained with different $\mathrm{DS}_{\text {total }}$, depending on the concentration of the acyl donor, and with a coupling reaction efficiency $>83 \%$. F urthermore, the ratio of the $\mathrm{DS}_{\text {adipate }}$ to $\mathrm{DS}_{\text {vinyl }}$ is relatively constant as a function of the molar ratio of DVA to inulin employed. This indicates that the reactions of diester formation and monoester formation proceed independently. Finally, increasing the DVA concentration resulted in poly(Inul-DVA) with higher $M_{n}$, such that at $40 \%$ theoretical DS, 3-4 inulin monomers are cross-linked together.

The time-course reactions of inulin with DVA, at 50 ${ }^{\circ} \mathrm{C}$, with different enzyme concentrations, are shown in Figure $1 \mathrm{~A}$. Taking into account the $\mathrm{DS}_{\text {total }}$, the initial incorporation of DVA into inulin molecules (reaction times $\leq 2 \mathrm{~h}$ ) increases with increased enzyme concentration: $1.2,2.6$, and $3.5 \%$ for 10,20 , and $40 \mathrm{mg} / \mathrm{mL}$ Proleather, respectively. However, the rate of adipate incorporation into the inulin structure changes significantly at later times. Furthermore, the observed reactivity at an enzyme concentration of $40 \mathrm{mg} / \mathrm{mL}$ was lower than that with $20 \mathrm{mg} / \mathrm{mL}$. This unusual behavior may be explained by the presence of a competing reaction that results in the hydrolysis of DVA. Such a competing reaction has been observed in other polycondensation reactions performed in organic media, where traces of water associated with the enzyme promote the hydrolysis of the highly activated divinyl esters such as DVA. ${ }^{15}$ The water content of the freeze-dried Proleather was $5.6 \%(\mathrm{w} / \mathrm{w}) ; 16$ hence, sufficient amounts of water are present in the reaction mixture, and this water content would be expected to increase as the enzyme concentration is increased, thereby resulting in lower yields of polycondensation product. Finally, the incorporation of DVA molecules by a single ester moiety (DS vinyl) foll owed al most the same trend for the different concentrations of enzyme (Figure 1A).

The variation of $M_{n}$ and the polydispersity of poly(Inul-DVA) versus DS total (Figure 1B) was studied for the same set of experiments described in Figure 1A. As

(15) Chaudhary, A. K.; Beckman, E. J .; Russell, A. J . Biotechnol. Bioeng. 1997, 55, 227. Brazwell, E. M.; Filos, D. Y.; Morrow, C. J . J . Polym. Sci. Part A: Polym. Chem. 1995, 33, 89.

(16) As determined with a Metler LJ 16 moisture analyzer (MettlerToledo AG, Switzerland). expected, the $M_{n}$ of poly(Inul-DVA) increased with DS total. Interestingly, there is a strong dependence of enzyme concentration on $\mathrm{M}_{\mathrm{n}}$; larger polymers are formed in the presence of higher enzyme concentrations. The reason for this enzyme concentration dependence is not clear.

The acylation of inulin with DVA could be conducted chemically, and this provides us with an opportunity to directly compare the enzymatic and chemical approaches. To that end, we foll owed a chemical synthesis procedure. ${ }^{17}$ The incorporation efficiency of DVA in the inulin backbone by the chemical approach $(53.4 \%)$ was similar to the results achieved for the enzymatic reaction $(56.7 \%$; Proleather concentration of $20 \mathrm{mg} / \mathrm{mL}$, reaction time of $72 \mathrm{~h}$ ); however, poly(I nul-DVA) obtained chemically had an $M_{n}$ of $9580 \mathrm{Da}\left(\mathrm{M}_{\mathrm{w}} / \mathrm{M}_{\mathrm{n}}=2.1\right)$, ca. $50 \%$ lower than that generated enzymatically. Thus, the enzymatic transformations yield higher molecular weight polymers than are achieved chemically. It is possible that the high degree of regioselectivity achieved enzymatically favors the formation of higher-molecularweight inulin-based polymers, and our continuing work on this subject is underway.

In summary, we have demonstrated the enzyme catalyzed polycondensation of a low-molecular-weight polysaccharide. To our knowledge, this is the first report dealing with enzyme-catalyzed polycondensation reactions using a polysaccharide as a monomer. These polymers may have commercial significance as polymeric drug carriers, ${ }^{18}$ as carriers for magnetic resonance imaging contrast agents such as Gd ${ }^{\prime \prime \prime}$ chelates, ${ }^{19}$ and as hydrogels. ${ }^{20,21}$

Acknowledgment. We thank Fundação para a Ciência e a Tecnologia (Praxis XXI, BD/18456/98) for the financial support to L.F. and the Biotechnology Research and Development Corporation for financial support to J S.D.

Supporting Information Available: Plot of $M_{n}$ as a function of reaction conversion for the different enzymes and NMR spectra of poly(Inul-DVA) (PDF). This material is available free of charge via the Internet at http://pubs.acs.org.

\section{020393W}

(17) Following a procedure by van Dijk-Wolthuis et al. (van DijkWolthuis, W. N. E.; Franssen, O.; Talsma, H.; Steenbergen, M. J .; Kettene-van den Bosch, J. J : Hennink, W. E. Macromol ecules 1995 $28,6317)$, the reaction was performed in $15 \mathrm{~mL}$ of anhydrous DMF containing $17 \mathrm{mM}$ Inulin and $200 \mathrm{mM}$ DVA and initiated by addition of $200 \mathrm{mg}$ of 4-DMAP as catalyst. The mixture was shaken $(250 \mathrm{rpm})$ at $50{ }^{\circ} \mathrm{C}$ for $72 \mathrm{~h}$ and then stopped by adding an equimolar concentration of concentrated $\mathrm{HCl}$ to neutralize the 4-DMAP. Afterwards, the reaction mixture was precipitated and washed with acetone. The precipitate was dissolved in Milli-Q water and dialyzed for 10 days at $4{ }^{\circ} \mathrm{C}$ against the same solvent. Finally, the solution was Iyophilized yielding $0.129 \mathrm{~g}$ (yield: $9.0 \%, \mathrm{DS}_{\text {total }}$ of $26.7 \%$ and $\mathrm{DS}$ vinyl of $3.0 \%$ ) of product.

(18) Vermeersch, J .; Schacht, E. Makromol. Chem. 1986, 187, 125.

(19) Corsi, D. M.; Elst, L. V.; Muller, R. N.; van Bekkum, H.; Peters, J. A. Chem. Eur. J . 2001, 7, 64.

(20) Vervoort, L.; van den Mooter, G.; Augustijns, P.; Busson, R.; Toppet, S.; Kinget, R. Pharm. Res. 1997, 14, 1730.

(21) We have used the free vinyl moieties that are present on the enzymatically derivatized inulin as "monomers" for free radical poIymerization. Two aqueous solutions of Poly(Inul-DVA) present DS viny of $8.6 \%$ and $18.7 \%$ gel after ca. $10 \mathrm{~min}$. The swelling ratio of these hydrogels in $0.01 \mathrm{M}$ citrate-phosphate buffer $\mathrm{pH} 7.0$ (at $25^{\circ} \mathrm{C}$, for 5 days) was 34.71 and 10.83 for Poly(Inul-DVA) DS $7.018 .6 \%$ and $18.7 \%$, respectively. Furthermore, under this $\mathrm{pH}$, inulin hydrogels undergo partial ester hydrolysis as confirmed by FT-IR. Therefore, these inulin hydrogels are attractive networks for designing drug delivery systems or matrix for tissue engineering. 